\title{
Number and Topographical Distribution of Retinal Ganglion Cells in Diurnal and Nocturnal Raptors
}

\author{
Número y Distribución Topográfica de Células Ganglionares \\ de la Retina en Rapaces Diurnas y Nocturnas
}

\begin{abstract}
Alessandra Coli ${ }^{1}$; Maria Rita Stornelli ${ }^{1}$; Giovanni Barsotti ${ }^{1}$; Carla Lenzi $^{1}$; Francesca Bogi $^{2}$ \& Elisabetta Giannessi ${ }^{1}$
\end{abstract}
COLI, A.; STORNELLI, M. R.; BARSOTTI, G.; LENZI, C.; BOGI, F. \& GIANNESSI, E. Number and topographical distribution of retinal ganglion cells in diurnal and nocturnal raptors. Int. J. Morphol.,36(3):955-961, 2018.

SUMMARY: Retinal Ganglion Cells (RGCs) in two diurnal raptors, the buzzard (Buteo buteo) and kestrel (Falco tinnunculus), and in two nocturnal raptors, the little owl (Athene noctua) and tawny owl (Strix aluco), were studied in order to highlight their topographical distribution, taking into account the soma size. Cell density (RGCs $/ \mathrm{mm}^{2}$ ) and median soma area from histological radial sections in four retinal fields (dorsal, ventral, temporal and nasal) were recorded in order to identify specialized retinal vision areas. The results showed a different RGCs distribution between diurnal and nocturnal raptors related to the location of the foveas and shape of the horizontal streak, confirming the bibliographic data. In diurnal raptors, a higher cell density was found in the temporal and central retinal fields as revealed by the presence of a temporal and a central fovea which showed a "horizontal streak". In nocturnal raptors the cell density was higher in the peripheral temporal field likely due to a temporal fovea. A peak in cell density observed in the ventral field, especially in the retina of little owls, might be linked to a more "radial visual streak". Comparing the data obtained we highlighted that the morphology and the number of RGCs are closely linked to the habitat and to the type of predation.

KEY WORDS: Retinal ganglion cells; Topographical distribution; Raptors.

\section{INTRODUCTION}

Sight plays a key role for birds. In fact, the eyeballs consist of $55 \%$ of the volume of the skull, while in humans they occupy only $5 \%$ (Jones et al., 2007). This feature might be related to the large image projected on the retina, contributing to the improvement of visual acuity.

In the avian literature, there are few studies investigating the differences in visual ability between diurnal and nocturnal raptors.

Diurnal raptors, which have eyes arranged laterally, have a central fovea and a temporal fovea (Inzunza et al., 1991; Jones et al.). They are both included in the "horizontal visual streak", a strip characterized by a high density of ganglion cells and which tends to be aligned with the horizon. The central fovea is mainly used for monocular vision, while the temporal one is for the binocular field. The relative positions vary according to where the eye is located within the head. While the central fovea generally does not change its position, the temporal one is closer to the central visual axis in raptors with more frontally placed eyes. The presence of both foveas enables them to understand the distance and the speed of prey.

The nocturnal raptors have frontally positioned eyes and with large pupils, thus the amount of light that stimulates the photoreceptors is increased. At the retinal level, the "visual streak" assumes a more radial and symmetrical shape in owls, (Lisney et al., 2012) compared to the much more elongated streak of diurnal raptors. Nocturnal raptors only have a temporal fovea (Jones et al.) which is associated with the frontal position of the eyes and improves the binocular vision.

We studied the retinal ganglion cells (RGCs), focusing on the relationship between their topographical distribution and soma size in retinalfields. The data on diurnal and nocturnal raptors are compared.

${ }^{1}$ Department of Veterinary Sciences, University of Pisa, Viale delle Piagge, 2, 56122, Pisa, Italy.

${ }^{2}$ Private practitioner, Pisa, Italy. 


\section{MATERIAL AND METHOD}

Sample collection. The retinae used for this study were taken from the right eyeballs of two specimens of diurnal raptors [(buzzard (Buteo buteo), kestrel (Falco tinnunculus)] and two specimens of nocturnal raptors [little owl (Athene noctua), and tawny owl (Strix aluco)]. All specimens came from the Center of Recovery of Seabirds and Waterfowl (Lipu, Livorno, Italy) where the raptors were taken following impact trauma or due to systemic diseases. Once euthanasia for the birds was agreed upon with by a certified protocol (Embutramide, $0.5-3 \mathrm{mg} / \mathrm{kg}$ intrapulmonary), post mortem sample collection was immediately carried out through trans conjunctival enucleation of the eyeball.

Sample processing. After removing the cornea, each sample was cut at the ora serrata and fixed in $4 \%$ neutral buffered formalin. For the histological procedure, each sample was washed several times in running water, and then immersed in a solution of $20 \%$ sucrose dissolved in PBS, for between 24 and $48 \mathrm{~h}$ for cryoprotection. The solution was changed once/twice. Samples were placed in special supports, with the pupil side up, and taking into account the ventro-temporal position of the pectin in order to orient the sections. The samples were covered with TissuTek O.C.T. and then processed with Isopentane and frozen at $-80{ }^{\circ} \mathrm{C}$ for a few minutes. Retinal radial serial $10 \mu \mathrm{m}$ thick sections were obtained by cryotome (Kryostat 1720, Leitz Wetzlar). This procedure enables only the RGCs be located, thus excluding the displaced amacrine cells. The sections were mounted on gelatinized slides and stored at $-20{ }^{\circ} \mathrm{C}$ until staining. The Nissl method (with $1 \%$ thionine blue) was used to study the Nissl body, the presence of which highlights the morphology of neurons. The slides were then removed from the freezer and dried for at least $30 \mathrm{~min}$. After cleaning the excess Tissutek O.C.T., the slides were immersed in a solution of chloroform and ethanol, in a ratio of 1:1, for four $\mathrm{h}$; during which time the slides were kept in the dark. After rehydration (two steps in absolute alcohol, two steps in $95^{\circ}$ alcohol, one step in $70^{\circ}$ alcohol, one step in $50^{\circ}$ alcohol, one step in $30^{\circ}$ alcohol and one step in distilled water, each one for five minutes ), the samples were immersed in a Nissl solution, at room temperature, for four minutes. After a quick wash with distilled water, the samples were dehydrated and coverslipped with Permount. RGCs were identified as cells showing the following cytological features (Duke-Elder, 1958; Cunningham, 2006):

- Polygonal cell body

- Presence of the Nissl substance in the cytoplasm

- Oval, euchromatic nucleus with round and light blue nucleolus
These parameters enabled the RGCs to be distinguished from glial cells (Coimbra et al., 2014), which have a small, roundish or slightly elongated cell body, reduced or non- detectable cytoplasm, and are negative to Nissl staining.

To detect the location of specific visual areas with sufficient precision, each section, previously oriented, was subdivided into dorsal (D), ventral (V), temporal (T) and nasal (N) fields (Fig. 1A). Ten slices at $100 \mu \mathrm{m}$ distance were taken into consideration from ora serrata (level 1), optic disc (level 3), and the half distance between levels 1 and 3 (level 2) (Fig.1B). A Nikon ECLIPSE Ni microscope, connected to Nikon-Digital.Sight DS-U1 digital image acquisition system, was used. RGCs were recorded and counted by NIS-Element Basic Research software at a magnification of 20x.

The number and size of the RGCs were calculated by analyzing a reference area $\left(0,06 \mathrm{~mm}^{2}\right)$ in the thickness of the RGCs layer (Fig.1C). For each section five reference areas were examined and the data obtained were reported to $1 \mathrm{~mm}^{2}$. The RGCs were classified on the basis of three different

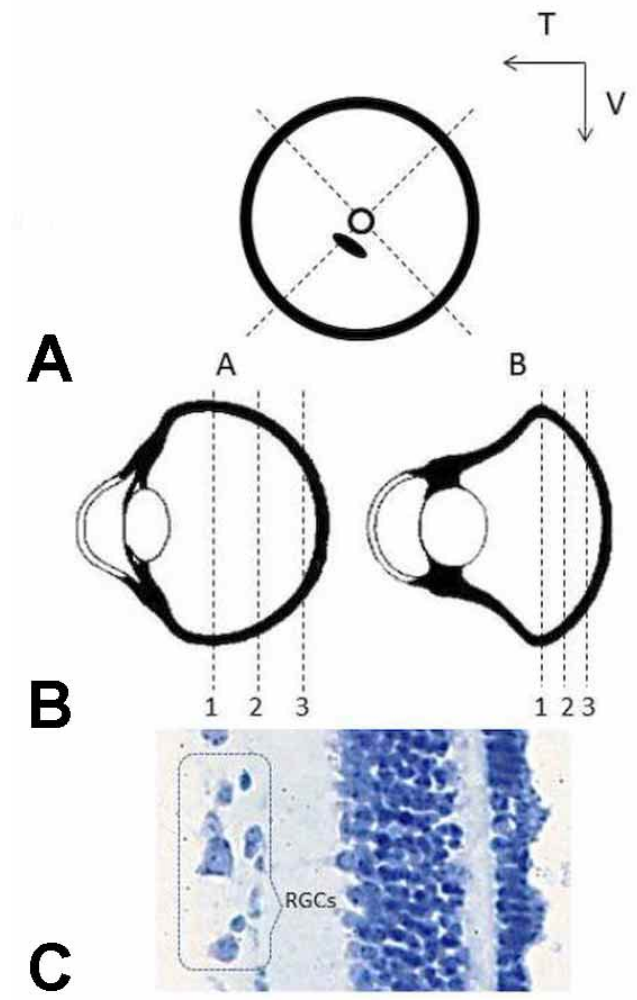

Fig. 1. A) Raptor retinal fundus: subdivision into four retinal fields (Dorsal; Temporal; Ventral; Nasal). The white shape represents the optic disc and the black shape the position of the pectin. B) Eyeball with retinal radial section at three levels (1: ora serrata, 2 : half distance between levels 1 and 3, 3: optic disc) in diurnal (A) and nocturnal (B) raptors; C) Histological features of raptor retina by Nissl method. RGCs are highlighted in the insert. 
ranges of median soma area $\left(<50 \mathrm{~mm}^{2}, 50-100 \mathrm{~mm}^{2}\right.$ and $>100 \mathrm{~mm}^{2}$ ) and the number of cells identified in each reference area were also reported. The results are given without corrections for shrinkage.

\section{RESULTS}

Figure 2 reports the number of $\mathrm{RGCs} / \mathrm{mm}^{2}$ related to section level $(1,2,3)$ and retinal fields $(\mathrm{D}, \mathrm{T}, \mathrm{V}, \mathrm{N})$ in diurnal (A) and nocturnal (B) raptors.

In diurnal raptors RGC density showed the highest value at the level of the optic disc (level 3). Only in the kestrel retina did level 2 show the highest cell density in the nasal field. For both diurnal raptors, the lowest value was in the peripheral level (level 1) of each field.

A
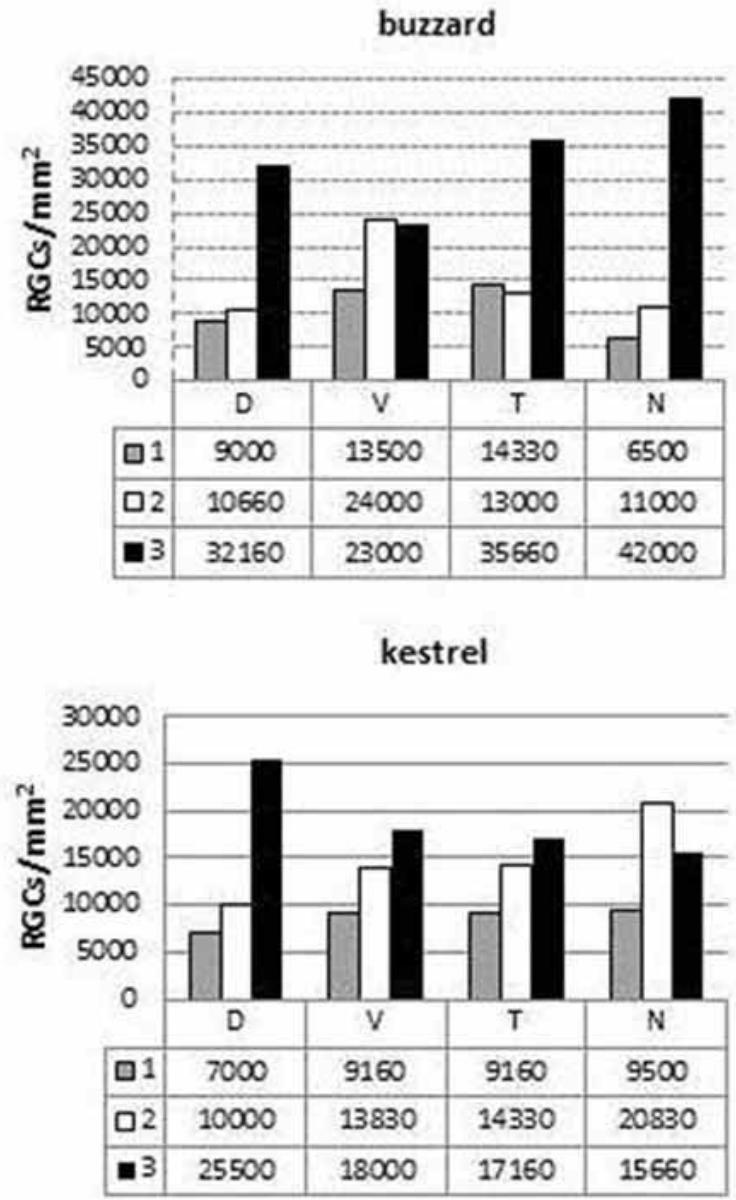

Both nocturnal raptors showed the highest RGC density in the ventral retinal field: while in the tawny owl, the RGC density was at the level of the ora serrata (level 1), and in the little owl it was at the level of the optic disc (level 3).

Figure 3 shows the evaluation of RGC density in temporo-nasal and dorso-ventral directions, required to identify the location of specific areas for vision.

In diurnal raptors, the RGC density for both temporo-nasal and dorso-nasal directions showed a Gaussian trend, with highest values at the level of the optic disc (T3, N3, D3, V3) in the buzzard retina. A greater homogeneity was detectable in the kestrel retina, with lower values in the peripheral fields of the temporo-nasal direction (T1, N1), while in the dorsal-ventral direction; the density also followed a Gaussian trend in the kestrel (D3, V3).

B
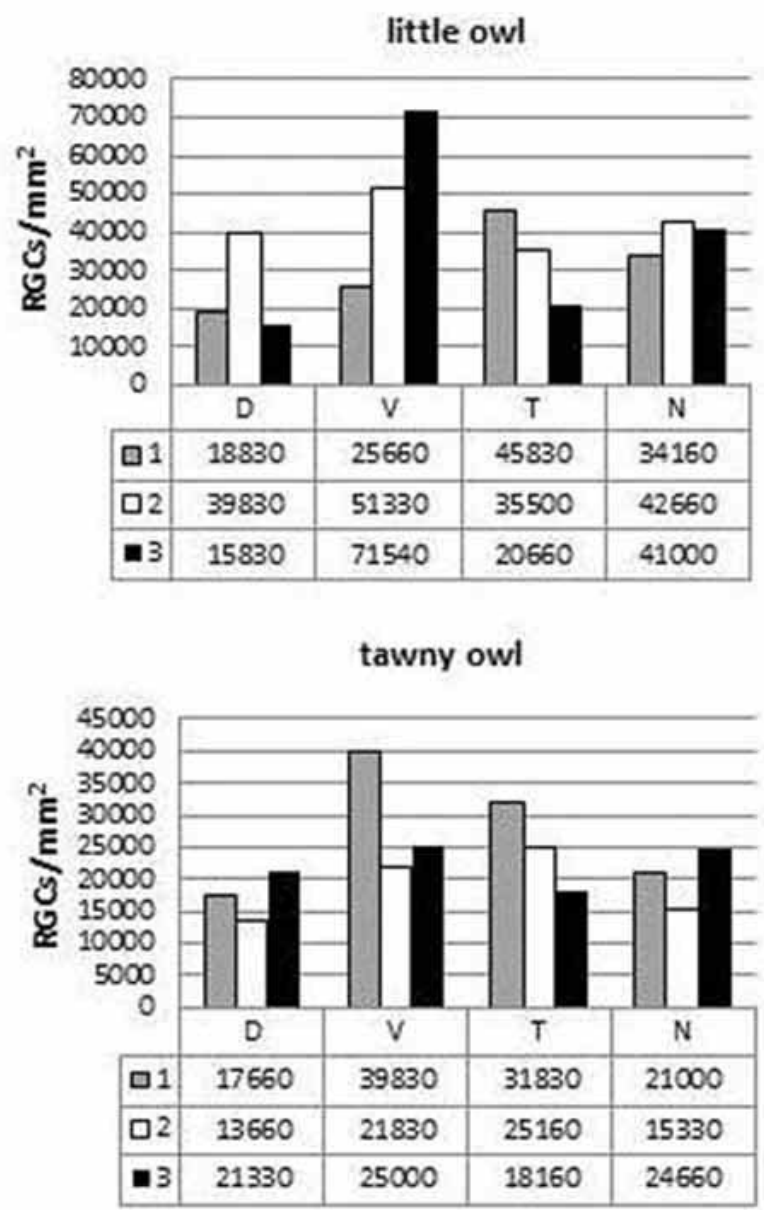

Fig. 2. Number of RGCs/mm² related to section level $(1,2,3)$ and retinal fields $(\mathrm{D}, \mathrm{T}, \mathrm{V}, \mathrm{N})$ in diurnal (A) and nocturnal (B) raptors. 

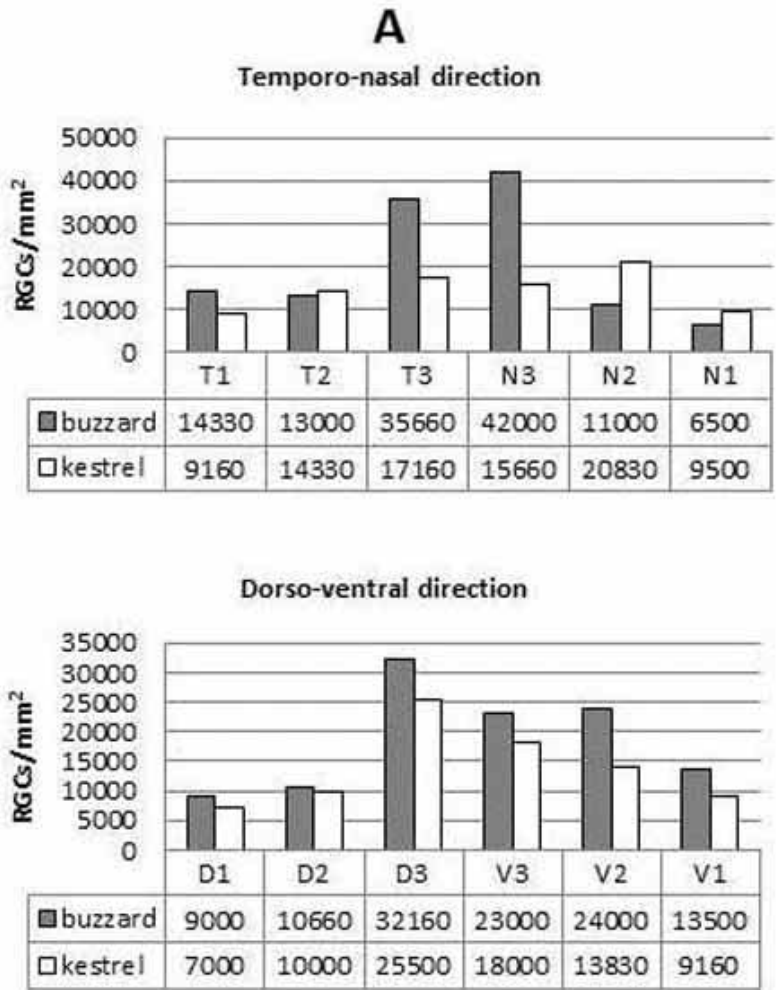

B

Temporo-nasal direction
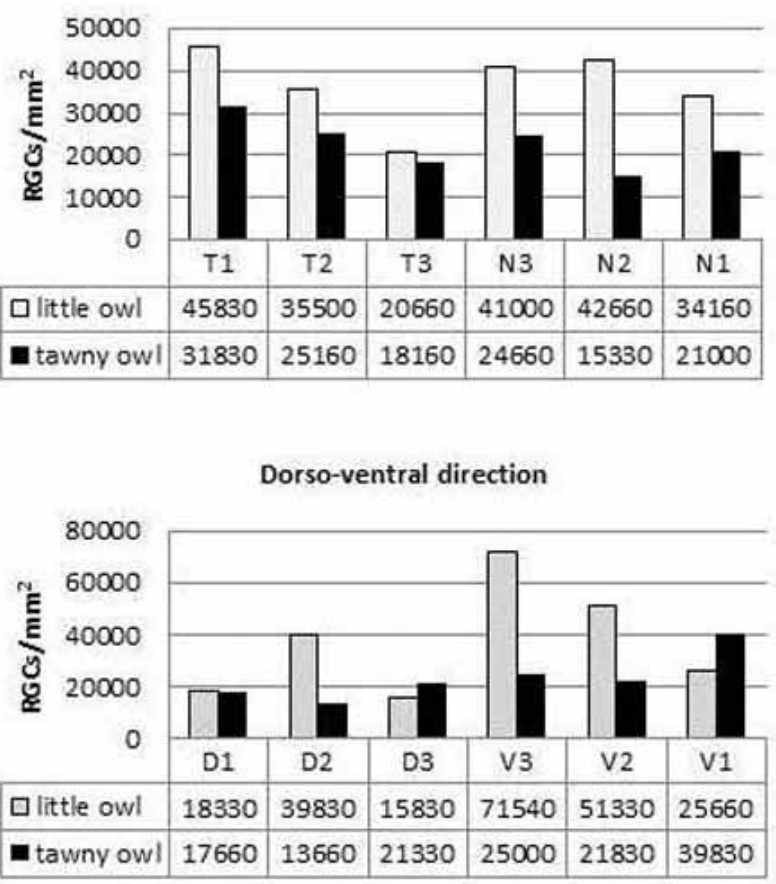

Fig. 3. Trend of RGC density in the temporo-nasal and dorso-ventral directions in diurnal (A) and nocturnal (B) raptors. (T1: external temporal; T2: intermediate temporal; T3: central temporal; N3: central nasal; N2: intermediate nasal; N1: external nasal; D1: external dorsal; D2: intermediate dorsal; D3: central dorsal; V3: central ventral; V2: intermediate ventral; V1: external ventral).

In the nocturnal raptors RGC density in the temporonasal direction was characterized by lower values in the central temporal (T3) and external/intermediate nasal (N1/N2) fields. Regarding the dorso-ventral direction, the ventral retinal fields showed a higher RGC density than the dorsal ones, especially in the central ventral position (V3) of the little owl retina and in the peripheral level (V1) of the tawny owl retina.

Figure 4 summarizes the percentage distribution of RGCs according to three different ranges of median soma area $\left(<50 \mathrm{~mm}^{2}, 50-100 \mathrm{~mm}^{2}\right.$ and $\left.>100 \mathrm{~mm}^{2}\right)$ in each retinal field and section level. Diurnal raptors lacked small RGCs (median soma area $<50 \mathrm{~mm}^{2}$ ) and the cells with median soma area $>100 \mathrm{~mm}^{2}$ were the most represented population in all retinal fields.

In nocturnal raptors, RGCs with a median soma area of $<50 \mathrm{~mm}^{2}$ were recorded only in the little owl retina, and most cells were in the rangeof $50-100 \mathrm{~mm}^{2}$, except for the ventral field at level 1 in the little owl retina. In fact here RGCs with a median soma of $<50 \mathrm{~mm}^{2}$ were the most common.

\section{DISCUSSION}

In the literature, the distribution of RGCs in raptors has been studied by many authors. Oehme (1961), Bravo \& Pettigrew (1981) and Lisney et al. highlighted that the number and distribution of RGCs in many species of nocturnal raptors (owls) differ with activity patterns and habitat. Species that hunt in open space and in more diurnal conditions show an elongated visual streak, while in more nocturnal owls, the visual streak is less defined and more radially shaped. In a comparative study of the visual pathways in Strigiformes, examining the tectofugal and talamofugal visual pathways, Gutiérrez-Ibáñez et al. (2012) suggested that the relative size of the owl's visual structure in the brain was related to the number of RGCs. Güntürkün (2000) reported that Strigiformes had an RGC density of up to $65,000 / \mathrm{mm}^{2}$, compared to $38,000 / \mathrm{mm}^{2}$ in humans. In the retina of Falconiformes (diurnal raptors) Inzunza et al. found a negative correlation between RGCs and cell body size and a rather homogenous population of these cells in temporal and nasal retinal fields. Some differences were instead found in Falconiformes and Accipitriformes in relation to visual 

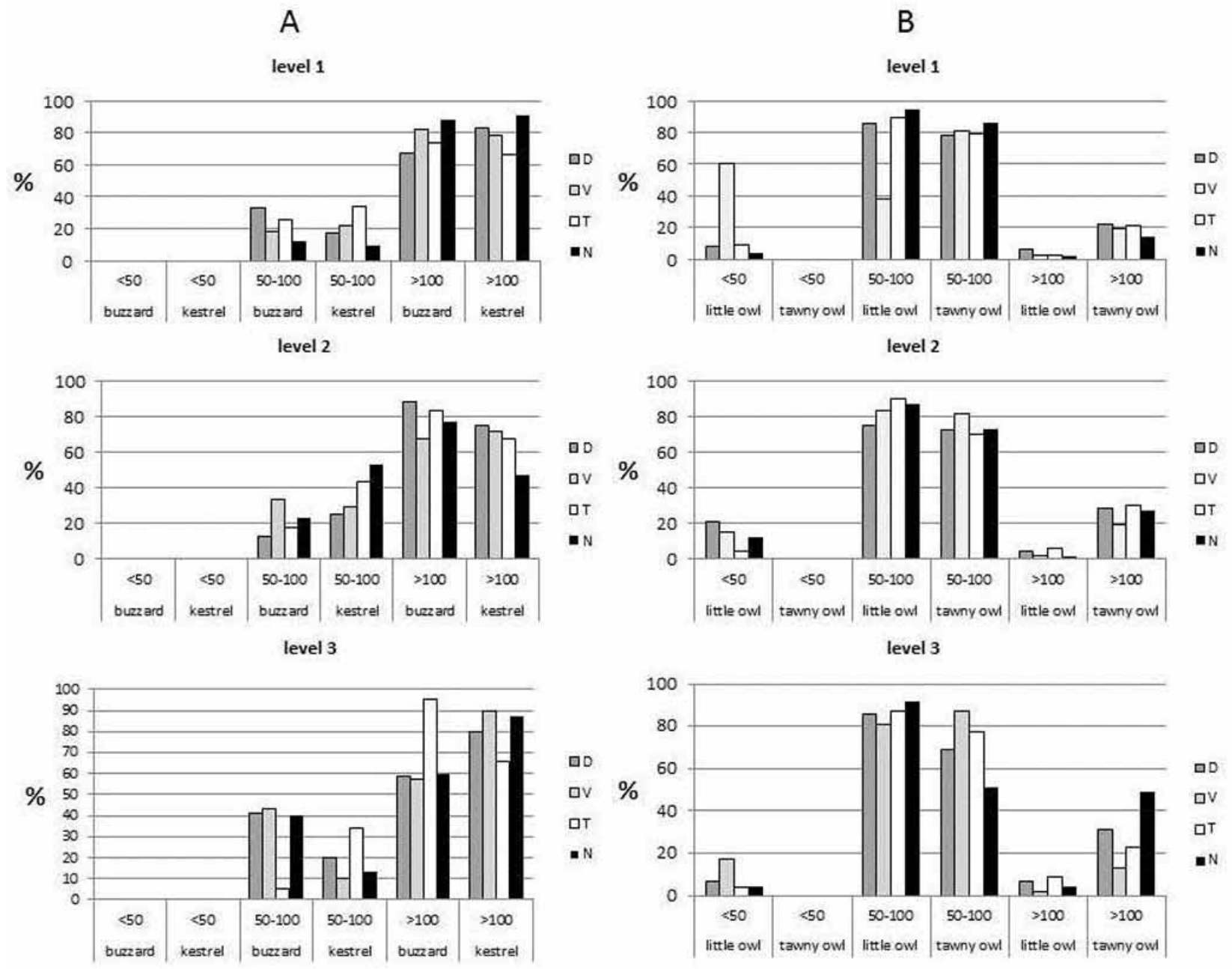

Fig. 4. Percentage distribution of RGCs according to range of medium soma area in each section level $(1,2,3)$ of the four retinal fields $(\mathrm{D}, \mathrm{V}, \mathrm{T}, \mathrm{N})$ in diurnal $(\mathrm{A})$ and nocturnal $(\mathrm{B})$ raptors.

fields and degree of eye movement for prey searching strategies (O'Rourke et al., 2010). The bibliographic notes reported in this study referred to the study of RGC density by "retinal wholemounts". Since in the highest density areas of avian retinas (Bravo \& Pettigrew), the RGCs become smaller and distributed into multiple sublayers, in this study the authors employed retinal radial sections to also identify the deeper RGCs and to distinguish the RGCs from the displaced amacrine cells which could lead to an overestimation of their number.

In this study the analysis of the RGC distribution differed between diurnal and nocturnal raptors in relation to the four retinal fields and the level of section (Fig. 2). The study of RGC density in the retina of diurnal raptors highlighted a greater uniformity of cell distribution with values generally lower than that observed in nocturnal raptors. In particular, in the owl, a high density of RGCs was found in the peripheral area of the ventral field (V3) that did not match the tawny owl retina. The evaluation of RGC density in temporo-nasal and dorso-ventral directions highlighted specialized retinal areas that are associated with foveas and visual streaks (Fig.3). In diurnal raptors, a peak density in temporal and central positions, especially in the buzzard retina was associated with the location of two foveas and an horizontal streak, in accordance with the literature (Inzunza et al.; Tucker, 2000), In both species of nocturnal raptors, the cell peak in the peripheral temporal field (T1) could be explained by the presence of a fovea in the extreme temporal position, as reported by Lisney et al. in nine species of owls. The presence of a streak in the nasal direction might be linked with the high RGC density found from N3 to N1. In addition, the analysis of the dorso-ventral density confirmed the particular outline of a more radial visual streak 
Table I. Feeding behavior of each diurnal and nocturnal raptor

\begin{tabular}{ccl}
\hline Common name & Species & \multicolumn{1}{c}{ Predatory behavior } \\
\hline Buzzard & Buteo buteo & $\begin{array}{l}\text { Eats birds, amphibians, reptiles; hunts in the woods or in open spaces, exclusively on the } \\
\text { ground. }\end{array}$ \\
Kestrel & Falco tinnunculus & $\begin{array}{l}\text { Eats small rodents, lizards, small birds and snakes; hunts especially in open spaces with low } \\
\text { vegetation. } \\
\text { Eats small vertebrates, predominantly in open spaces, hunting on the ground after a short } \\
\text { flight. }\end{array}$ \\
Athene noctua & Eats small and medium sized mammals, amphibians and birds, hunting the prey quickly. \\
\hline
\end{tabular}

in the ventral direction, as reported by Lisney et al. in the barred owl, northern saw-whet owl and barn owl. Previous studies (Inzunza et al.; Linsey et al., 2012) have reported that smaller cells were concentrated in the central part of the retina, at the fovea and "horizontal visual streak" for a mechanical fit, whereas larger RGCs were found in the periphery of the retina. Our results agree with such data because the RGC soma size was inversely proportional to the cell density in all the retinal fields and section levels in the raptors examined. In addition, the recording of a higher RGC density in the retinae of nocturnal raptors could support the hypothesis that, in order to overcome the shortage of light, an increase in the number of RGCs would be directly responsible for a better projection of the image on the visual cortex. In order to correlate the RGC distribution and morphometry with feeding behavior (Table I), the presence of two foveas and a well-developed "horizontal visual streak" in diurnal raptors could be directly related to the type of hunting and the environment in which they live. In fact, we found a particular area of higher RGC density attributable to a temporal fovea, which is used for binocular vision, and a progressively higher density at the central retinal field (level 3) related to a fovea for monocular vision. The presence of both foveas enables these birds to have a better perception of the distance and speed of the prey, which are captured after a period of observation. Conversely, nocturnal raptors have frontal eyes, with very large pupils and a only one temporal fovea with a "radial visual streak". In fact in the two nocturnal examined raptors there was a high RGC density in the ventral direction, which we had not found in diurnal raptors. This could be explained by the presence of a tapetum lucidum in the dorsal fields, located immediately above the optic disc, which we observed at the opening of the eyeballs. This feature might be a functional adaptation linked to the conformation of the eyeball itself and to the refractive angle of the light amplified by the tapetum. There are no studies on avian species that refer to our interpretation, which therefore requires further investigation and confirmation. The different organization of RGCs in the foveas and the visual streak between diurnal and nocturnal raptors could also be explained by the "terrain theory" (Hughes, 1977), according to which retinal topography is closely related to the parti- cular habitat characteristics of different animals. According to this theory, diurnal raptors, which live and hunt mainly in open spaces dominated by the horizon, have a significantly developed "horizontal" visual streak, which overlaps the horizon itself, enabling them to have a better panoramic and stereoscopic vision. Instead in nocturnal raptors, the "horizon" loses relevance and the same anatomical outline of the visual streak changes, becoming more "radial". This is because they hover in the dark or under low light conditions, in a short distance from their position, also needing the sense of hearing to locate the prey (Brown, 1997).

\section{ACKNOWLEDGMENTS}

We are grateful to Renato Ceccherelli, DVM, Health Director of the Center of Recovery Seabirds and Waterfowl (Lipu, Livorno, Italy) for his assistance and collaboration in the sample collection.

COLI, A.; STORNELLI, M. R.; BARSOTTI, G.; LENZI, C.; BOGI, F. \& GIANNESSI, E. Número y distribución topográfica de células ganglionares de la retina en rapaces diurnas y nocturnas. Int. J. Morphol., 36(3):955-961, 2018.

RESUMEN: Se estudiaron las células ganglionares de la retina (RGC) en dos aves rapaces diurnas, el ratonero (Buteo buteo) y el cernícalo (Falco tinnunculus), y en dos aves rapaces nocturnas, el mochuelo (Athene noctua) y el búho leonado (Strix aluco), buscando resaltar su distribución topográfica, teniendo en cuenta el tamaño del soma. Se registraron la densidad celular (RGCs $/ \mathrm{mm}^{2}$ ) y la media del área del soma de las secciones histológicas radiales en cuatro campos retinianos (dorsal, ventral, temporal y nasal) para identificar áreas de visión retinianas especializadas. Los resultados mostraron una distribución diferente de RGCs entre las rapaces diurnas y nocturnas relacionadas con la ubicación de las fóveas y la forma de la línea horizontal, lo que confirma los datos bibliográficos. En las aves rapaces diurnas, se encontró una densidad celular más alta en los campos de retina temporales y centrales como lo revela la presencia de una fóvea temporal y central que 
mostraba una "veta horizontal". En aves rapaces nocturnas, la densidad celular fue mayor en el campo temporal periférico probablemente debido a una fóvea temporal. Un aumento en la densidad celular, observado en el campo ventral, especialmente en la retina de los pequeños buhos, podría estar relacionado con una "línea visual radial". Comparando los datos obtenidos, resaltamos que la morfología y el número de RGC están estrechamente relacionados con el hábitat y el tipo de depredación.

PALABRAS CLAVE: Células ganglionares de la retina; Distribución topográfica; Aves rapaces.

\section{REFERENCES}

Bravo, H. \& Pettigrew, J. D. The distribution of neurons projecting from the retina and visual cortex to the thalamus and tectum opticum of the barn owl, Tyto alba, and the burrowing owl, Speotyto cunicularia. J. Comp. Neurol., 199(3):419-41, 1981.

Brown, L. Birds of Prey. London, Chancellor Press, 1997.

Coimbra, J. P.; Collin, S. P. \& Hart, N. S. Topographic specializations in the retinal ganglion cell layer of Australian passerines. J. Comp. Neurol., 522(16):3609-28, 2014.

Cunningham, J. G. Manuale di Fisiologia Veterinaria. $3^{\text {st }}$ ed. Rome, Antonio Delfino Editore, 2006.

Duke-Elder, S. The emergence of vision in the animal world. Ann. R. Coll. Surg. Engl., 23(1):1-24, 1958.

Güntürkün, O. Sensory Physiology: Vision. In: Whittow, G. C. Sturkie's Avian Physiology. $5^{\text {th }}$ ed. San Diego, Academic Press, 2000.

Gutiérrez-Ibáñez, C.; Iwaniuk, A. N.; Lisney, T. J. \& Wylie, D. R. Comparative study of visual pathways in owls (Aves: Strigiformes). Brain Behav. Evol., 81(1):27-39, 2013.

Hughes, A. The Topography of Vision in Mammals of Contrasting Life Style: Comparative Optics and Retinal Organisation. In: Crescitelli, F. (Ed.). The Visual System in Vertebrates. Handbook of Sensory Physiology, vol 7/5. Heidelberg, Springer, 1977.

Inzunza, O.; Bravo, H.; Smith, R. L. \& Angel, M. Topography and morphology of retinal ganglion cells in Falconiforms: a study on predatory and carrion-eating birds. Anat. Rec., 229(2):271-7, 1991.

Jones, M. P.; Pierce Jr., K. E. Jr. \& Ward, D. Avian vision: A review of form and function with special consideration to birds of prey. J. Exot. Pet Med., 16(2):69-87, 2007.

Lisney, T. J.; Iwaniuk, A. N.; Bandet, M. V. \& Wylie, D. R. Eye shape and retinal topography in owls (Aves: Strigiformes). Brain Behav. Evol., 79(4):218-36, 2012.

O'Rourke, C. T.; Hall, M. I.; Pitlik, T. \& Fernández-Juricic, E. Hawk eyes I: diurnal raptors differ in visual fields and degree of eye movement. PLoS One, 5(9):e12802, 2010.

Oehme, H. Vergleichend-histologische Untersuchungen an der Retina von Eulen. Ph.D. Thesis. Berlin, Humboldt-Univ., 1961.

Tucker, A. V. The deep fovea, sideways vision and spiral flight paths in raptors. J. Exp. Biol., 203(Pt. 24):3745-54, 2000.

\author{
Corresponding Author: \\ Alessandra Coli \\ Department of Veterinary Sciences \\ University of Pisa \\ Viale delle Piagge, 2 \\ 56122, Pisa \\ ITALY
}

Email: alessandra.coli@unipi.it

Received: 01-02-2018

Accepted: 19-03-2018 